\title{
KORESPONDENCIJA IVANA FIAMINA S FRANJOM RAČKIM (1861. - 1889.) ${ }^{1}$
}

Dr. sc. Maja Polić

Hrvatska akademija znanosti i umjetnosti

Zavod za povijesne i društvene znanosti u Rijeci

Ružićeva 5, HR - 51000 Rijeka

polic@hazu.hr
UDK 930.253(044)Fiamin, I.+Rački, F.

Pregledni članak

Primljeno: 19. 12. 2019.

Prihvaćeno: 19. 5. 2020.

DOI: $10.21857 / 9 \mathrm{e} 31$ lhvjgm

Tea Dimnjašević, studentica

Odsjek za povijest

Filozofski fakultet Sveučilišta u Rijeci

Sveučilišna avenija 4, HR - 51000 Rijeka

tdimnjasevic@gmail.com

U članku je govor o sadržaju korespondencije riječkoga svećenika Ivana Fiamina upućene kanoniku i političaru dr. Franji Račkome. Ivan Fiamin (1833. - 1890.) osnovno je i gimnazijsko obrazovanje završio u nekadašnjoj Rijeci, nakon čega završava bečki Pazmaneum. Neko je vrijeme proveo u Senju, nakon čega odlazi u tadašnju Rijeku, gdje ostaje sve do svoje smrti. Književnim se radom počeo baviti na poticaj svojega nekadašnjeg gimnazijskog učitelja Frana Kurelca slijedeći filološke nazore Kurelčeve riječke filološke škole. Tijekom Fiaminova stasanja, ali i znatno kasnije, Kurelac je bio njegov mentor $i$ oslonac u brojnim problemima, napose nacionalnim, koji nisu bili neznatni. Fiaminova korespondencija upućena Račkome sastoji se od dvadeset $i$ četiri pisma $i$ pohranjena je u Arhivu Hrvatske akademije znanosti i umjetnosti. Pisma obraduju Fiaminovo književno djelovanje, posao, školska pitanja $i$ staranja za učenike itd. Radom se, uz pomoć historijske kritičke metode, metoda analize i sinteze i deskriptione metode, nastoji osvijetliti segmente Fiaminova života i djelovanja.

Ključne riječi: Ivan Fiamin; Franjo Rački; Rijeka; korespondencija.

1 Članak je nastao u okviru znanstvenoistraživačkoga projekta Hrvatski kulturni krug Rijeke u 19. stoljeću na Sveučilištu u Rijeci i zaveden je pod šifrom 'uniri-human-18 591189 '. 


\section{Uvod}

Analizirajući građu i literaturu može se zaključiti kako je Ivan Fiamin rijetko bio predmetom znanstvenoga ili stručnog istraživanja. Većina dostupne literature predstavlja ga kroz njegove biografske podatke. O Ivanu Fiaminu pisali su prof. dr. sc. Irvin Lukežićn i Josip Martinolić3 , a svoje je mjesto zaslužio i u Albumu zaslužnih Hrvata XIX. stoljeća. ${ }^{4}$ Profesor Lukežić predstavlja Fiaminov životni put od rođenja preko različitih razina školovanja i službovanja pa sve do posljednjih dana njegova dinamičnog života. Posebnu pozornost pridaje Fiaminovu djelu Radnja čovjeku dužnost i blagodat ${ }^{5}$ koje je jedino tiskano pod njegovim imenom. Kako navodi, Fiamin u ovoj knjizi polazi od pretpostavke da je svaki pojedinac definiran svojim djelovanjem te da se jedino radom može postići napredak. Na ponešto drugačiji pristup Fiaminovu životu i djelu nailazimo kod Josipa Martinolića: autor čitatelje s njime upoznaje kroz vlastita sjećanja oslikavajući nam i onovremene prilike u kojem je Fiamin djelovao.

\section{Ivan Fiamin i tadašnja Rijeka}

Jedna od iznimno značajnih ličnosti riječkoga XIX. stoljeća jest i Ivan Fiamin. Rodio se 9. srpnja 1833. u Voloskome. Bio je sin iskusnog mornara Ivana Jurjeva i Marije rođene Tomašić. U tadašnju Rijeku doselio se još kao dječak zajedno sa svojim roditeljima i bratom i ondje je pohađao i završio pučku školu i gimnaziju. U navedenu razdoblju posebno je zanimljiv položaj tadašnje Rijeke, koja se kao opsegom manji grad razvila na desnoj strani potoka Rječine uz njezin utok u Riječki zaljev Jadranskoga mora, dok se Sušak u XIX. stoljeću razvio na lijevoj strani Rječine. ${ }^{6}$ Riječko područje podijeljeno je između te dvije upravno-državne cjeline. Sama Rijeka, rekosmo - grad uz desnu obalu ušća potoka Rječine u Riječki zaljev Jadranskoga mora - tijekom XIX. stoljeća mijenjala je svoje gospodare, a 1868. godine Hrvatsko-ugarskom nagodbom dolazi pod neposrednu upravu Pešte. Sušak, naselje u nastajanju istočno od Rječine, kao i druga obalna područja Kvarnerskoga primorja do Novoga Vinodolskoga (a istok je Vojna krajina) bili su dio Banske Hrvatske, dakle posred-

2 Irvin Lukežić, Pučki prosvjetitelj Fiamin, Fluminensia, I, 1, Rijeka, 1989., str. 35-38; isti, Ivan Fiamin, Crikvenica, 1999.

3 Josip Martinolić, Ivan Fiamin. Sjećanje Josipa Martinolića, Rijeka, 1890.

4 Milan Grlović, Album zaslužnih Hrvata XIX. stoljeća, Zagreb, 1900.

5 Radnja čovjeku dužnost i blagodat, Zagreb, 1870.

6 Petar Strčić, Rijeka od kraja XVIII. stoljeća do 1918. Prilog za nacrt povijesne sinteze, Rijeka, I, 1, Rijeka, 1994., str. 49-72. 
no dio Ugarske. Na zapadno predgrađe Rijeke nastavljao se cislajtanijski, austrijski prostor, i to Kastavština i Liburnijska Istra, a nasuprot su također bečki Kvarnerski otoci. Hrvatsko-ugarskom nagodbom ostao je neriješen problem pripadnosti tadašnje Rijeke, koja se uskoro ipak našla izlučena iz Banske Hrvatske, pod neposrednom upravom Budimpešte (sve do 1918.).

Grad je i ranije, kao dvorsko habsburško dobro, naizmjence mijenjao svoj unutardržavni pripadajući status, tako da je povremeno ulazio u sastav Kranjske ili, primjerice, Severinske županije u okviru Banske Hrvatske; ${ }^{7}$ a kratkotrajno je pripadao i Bonapartinim Ilirskim provincijama. ${ }^{8}$ Problem je i sâm unutarnji razvoj Rijeke u kojemu je vladajući bio uglavnom tanak, anacionalni sloj, dok je najveći dio donjega društvenoga hijerarhijskoga sloja bio hrvatski, koji je bio i apsolutno većinsko stanovništvo. ${ }^{9}$

Veoma je zanimljiva priča prema kojoj je Fiamin, po uzoru na svojega oca, isprva želio postati pomorac, ali je ipak - vidjevši pomorsku nesreću koja se dogodila u blizini riječke obale - odlučio upisati latinsku školu, odnosno riječku gimnaziju. ${ }^{10}$ Majka će imati veliku ulogu u njegovu životu, a posebno nakon što zarana ostane bez oca - nastavila ga je odgajati u duhu pobožnosti i pod strogom stegom odgovornosti i radišnosti. Te karakteristike koje je Fiamin usvojio uvelike su dolazile do izražaja tijekom njegova školovanja, a posebno za vrijeme pohađanja gimnazije, kada je počeo iskazivati zanimanje za književnost i narodni jezik. Godine 1849. upoznaje Frana Kurelca, ${ }^{11}$ novog profesora „,narodnog” (hrvatskog) jezika

$7 \quad$ Na čelo Severinske županije postavljen je riječki guverner, koji je u isto vrijeme obavljao dužnost kapetana riječkoga i kapetana bakarskoga. Povijest Rijeke, ur. Danilo Klen, Rijeka, 1988., str. 150.

$8 \quad$ Isto, str. 165-166; Danilo Klen, Privredno stanje Rijeke u doba Ilirije. Prema suvremenim izvještajima Trgovinske komore, Zagreb, 1959.

$9 \quad$ Povijest Rijeke, n. dj., na više mjesta.

10 Riječku gimnaziju osnovali su davne 1627. godine isusovci, a djelovala je u zgradi pokraj katedrale sv. Vida. Gimnazijsko obrazovanje trajalo je šest godina, a izvodilo se na latinskom jeziku sve do 1848./1849. godine, kada se uz velike zasluge profesora Frana Kurelca nastava počinje održavati i na hrvatskom jeziku. Društvene i političke promjene uvelike su utjecale i na djelovanje te gimnazije, koja se 1868. godine morala preseliti na novu lokaciju, u zgradu na današnjoj Fiumari, a 1899. gimnazija započinje s radom u zgradi na Sušaku, gdje je i danas smještena. Petar Strčić, Leksikon istaknutih učenika gimnazije, Sušak - Rijeka, 2017., str. 9-13.

11 Fran Kurelac (1811. - 1874.) hrvatski je književnik i filolog, predvodnik riječke filološke škole, koja je, uz zagrebačku i zadarsku, nastala u okviru hrvatskoga narodnog preporoda radi standardizacije hrvatskoga jezika. Svoja stajališta Kurelac je javnosti prezentirao u godišnjim izvješćima tadašnje riječke gimnazije. Tako je u izvješću za 1851./1852. godinu objavio prilog Kako da sklanjamo imena? ili greške hrvatskih pisac glede sklonjovanja osobito 2-a padeža množine, kojim je pokrenuo raspravu o nastavku genitiva množine imenica, što će biti predmetom prijepora između dviju filoloških škola. Kurelac je ostao upamćen kao izuzetan učitelj hrvatskog jezika u 
u riječkoj gimnaziji, a koji će imati velik utjecaj na njega i otvoriti mu put daljnjeg školovanja i rada na sebi. Kurelac je bio glavni predstavnik riječke filološke škole te je okupio nekoliko svojih učenika koji su neko vrijeme zagovarali Kurelčeve jezikoslovne ideje te ih koristili u svojim pisanim djelima. Uz Fiamina, tome su krugu pripadali Ivan Dežman, ${ }^{12}$ Ivan Črnčić, ${ }^{13}$ Fran Pilepić itd. ${ }^{14}$ Neko su vrijeme Kurelčeva jezična stajališta prihvaćali i Marijan Derenčin, ${ }^{15}$ Vinko Pacel, ${ }^{16}$ Franjo Rački ${ }^{17}$

riječkoj gimnaziji, gdje je radio od 1849. godine. Tijekom svoje učiteljske karijere ostvario je znatan utjecaj na nekolicinu riječkih ličnosti, a među ostalima i na Erazma Barčića te Ivana Fiamina. Bio je sljedbenik Ljudevita Gaja, a pristaša sveslavenske ideje, kojoj je podredio i svoju jezičnu koncepciju. Hrvatska enciklopedija, VI, Zagreb, 2004., str. 324.

12 Ivan Dežman, (Rijeka, 6. V. 1841. - Zagreb, 24. X. 1873.), hrvatski liječnik, leksikograf i književnik. Godine 1871./72. bio je glavni urednik Vienca. Sastavio je prvi hrvatski medicinski rječnik (1868.) služeći se jezičnim savjetima i rukopisnom građom F. Kurelca. Objavljivao je i znanstveno-prosvjetne članke (Vienac, 1869.-73.). Osnovao je društvo za popularna znanstvena predavanja (1869.), u kojem je držao predavanja iz higijene (skupljena u knjizi Čovjek prema zdravlju $i$ ljepoti, 1872.). Hrvatski leksikon, III, Zagreb, 2001., str. 178.

13 Ivan Črnčić (Crnčić) (Polje na Krku, 2. V. 1830. - Rim, 7. I. 1897.), hrvatski povjesničar i slavist. Studij bogoslovije završio je u Gorici (Gorizia). Zaređen je za svećenika 1856., a potom je nastavio studij teologije u zavodu Augustineum u Beču, gdje je doktorirao 1861. Iste je godine tajnik krčkoga biskupa Ivana Josipa Vitezića. Godine 1862. postao je kanonik crkve sv. Jeronima u Rimu, a 1863. ravnatelj Hrvatskoga zavoda sv. Jeronima i na toj je dužnosti ostao do smrti. Autor je mnogobrojnih monografija, studija, rasprava i članaka iz hrvatske kulturne i crkvene povijesti. Hrvatski leksikon, II, Zagreb, 2000., str. 479.

14 Zlatko Vince, Putovima hrvatskoga književnog jezika (Lingvističko kulturno povijesni prikaz filoloških škola i njihovih izvora), Zagreb, 2002., str. 428.

15 Marijan Derenčin (Rijeka, 24. XI. 1836. - Zagreb, 8. II. 1908.), hrvatski dramatičar, pravni i politički pisac i novinar. Pravo je doktorirao u Beču 1860. Bio je dugogodišnji saborski zastupnik, odvjetnik, kriminolog i penolog. U književnosti se javio 1883. komedijom Tri braka (praizvedba u Zagrebu, 1891.), a sklonost prema humoru pokazao je i kraćim sastavcima u satiričnim listovima Muha (1897.) i Satir (1901.), koje je sâm pokretao i uređivao. Hrvatski leksikon, III, 2001., str. 152.

16 Vinko Pacel autor je „prve javne polemike o Kurelčevu jeziku”. Diana Stolac, Riječki filološki portreti, Rijeka, 2006., str. 31.

17 Franjo Rački (Fužine, 25. studenoga 1828. - Zagreb, 13. veljače 1894.), potonji kanonik u Đakovu, pa u Zagrebu, također je iz trgovačke obitelji. U Beču je završio studij teologije te je zaređen za svećenika. Studij filozofije i teologije polazio je u Beču, gdje je doktorirao 1855. godine. U Senju je predavao matematiku, fiziku i teologiju. U razdoblju 1857. - 1860. u Rimu istražuje vrela o hrvatskoj povijesti. U Zagrebu je političar od 1860., te sa Strossmayerom osniva Narodnu stranku i glavni je urednik njezina lista Pozor, kasnije Obzor. U više je navrata zastupnik u Saboru Banske Hrvatske. Bio je i glavni školski nadzornik. S V. Jagićem pokreće časopis Književnik. Prvi je predsjednik JAZU (1866.-86.). Zbog loše provedene revizije Hrvatsko-ugarske nagodbe, Rački se, kao i nešto ranije Strossmayer, 1874. povlači iz politike. Bio je kanonik u Đakovu te u Zagrebu. Nakon pada bana I. Mažuranića 1880. osniva opozicijsku Neodvisnu narodnu stranku. Smatra ga se osnivačem moderne hrvatske historiografije. Autor je mnogo radova iz starije hrvatske i bosanske povijesti, glagoljaštva itd., ali i aktualne situacije (npr. o tadašnjoj 
i Tadija Smičiklas. ${ }^{18}$ Činjenica da sam Kurelac i pripadnici riječke filološke škole nisu bili učeni jezikoslovci te da nisu bili skloni pisanju normativnih priručnika, odnosno pravopisa, gramatike i rječnika, za razliku od zagrebačke filološke škole, u kojoj je „djelovala skupina školovanih filologa, čija se jezična koncepcija vidi u nizu temeljnih standardoloških djela koja su objavili - gramatika i rječnika" pridonijela je krahu riječke škole. ${ }^{19}$

Tijekom cijeloga svojeg školovanja Fiamin je bio uzoran učenik, izrazito znatiželjne ćudi i nadarenosti te se prema svim svojim obavezama odnosio s jednakim poštovanjem. To potvrđuju i njegove svjedodžbe, prema kojima je iz gotovo svih predmeta bio ocijenjen kao uspješan, odnosno eminens. Nakon završena tri razreda pučke škole i šest razreda gimnazije u Rijeci, Fiamin odlazi u senjsko sjemenište, gdje pod budnim okom tadašnjeg biskupa Mirka Ožegovića pohađa senjsku gimnaziju i veoma uspješno polaže ispit zrelosti. ${ }^{20} \mathrm{U}$ svojim sjećanjima Josip Martinolić piše: „Prigodom ispita zrelosti što ga je polagao u Senju, u prisutnosti biskupa Ožegovića, Fiamin steče svojimi umnimi i učenimi odgovori toliko priznanje, da ga biskup posla na bogoslovne nauke u Beču." ${ }^{21}$ Odlazak u Beč na daljnje obrazovanje za Fiamina predstavlja životnu prekretnicu. Ondje se suočio s dilemom oko nastavka školovanja; njegov učitelj F. Kurelac poticao ga je na školovanje za učitelja, dok je s druge strane njegova majka imala želju

Rijeci). I Rački je za južnoslavenstvo, pa za jugoslavenstvo (u nas se nerijetko izjednačuju pojmovi južnoslavenstvo i jugoslavenstvo, najčešće se koristi taj posljednji oblik. No, oni su i suštinski različiti). Južnoslavenstvo, prema F. Račkome, trebalo se ostvarivati na kulturnom i političkom području; najprije je trebalo postići „književnu uzajamnost” s osloncem na slavensku tradiciju i stremeći jedinstvenoj južnoslavenskoj kulturi, i to preko impulsa Jugoslavenske akademije, što bi u konačnici trebalo osigurati nacionalni opstanak ,južnoslavena”, koji se sastoje od četiriju grana - Hrvata, Slovenaca, Srba i Bugara, te od triju narječja - hrvatskoga ili srpskog, slovenskog i bugarskog. Jugoslavenstvo nastaje s razvojem nacionalne politike u novim osamostaljenim državama u XIX. stoljeću, u Crnoj Gori, Bugarskoj i Srbiji. Tako se napušta i spomenuta komponenta Sv. Stolice o zbližavanju Katoličke crkve i pravoslavnih crkava. O tome: Mirjana Gross, „Ideja Jugoslovjenstva" Franje Račkoga u razdoblju njezine formulacije (1860-1862), Historijski zbornik, XXIX-XXX, Zagreb, 1976. - 1977., str. 331 i dalje; Petar Strčić, Franjo Rački - inspirator Strossmayerovih ideja, n. dj. O Račkome usp. Mirjana Gross, Vijek i djelovanje Franje Račkoga, Zagreb, 2004.; ista, Franjo Rački: ključne godine profesionalnoga povjesničara, Radovi Filozofskog fakulteta Sveučilišta u Zagrebu, Zavod za hrvatsku povijest, 34/36, Zagreb, 2001./2004., str. 63-88; Izbor iz djela. Franjo Rački (priredio Jakša Ravlić), Zagreb, 1969.

18 Ivo Pranjković, Predgovor, u: Jezikoslovne rasprave i članci, priredio Ivo Pranjković, Zagreb, 1999., str. 13.

19 D. Stolac, n. dj., str. 33.

20 J. Martinolić, n. dj., str. 2.

21 Isto, str. 7. 
usmjeriti ga prema svećeničkom pozivu. Velika ljubav i poštovanje koje je osjećao prema majci bili su presudni da se odluči za svećenički poziv. ${ }^{22}$

U bečkom sjemeništu Pazmaneum ${ }^{23}$ Fiamin je proveo četiri godine (1852. 1856.), a po završetku studija bio je primoran vratiti se u Senj, gdje je nedostajalo svećenika, i odmah preuzeti brojne obaveze. U Senju je obavljao funkciju prefekta sjemeništa, vjeroučitelja u pučkoj školi, ekshortatora i učitelja u gimnaziji. Iako je primarno bio svećenik i volio je taj poziv, Fiamin se nije u potpunosti odrekao i učiteljskog poziva, koji je također iznimno volio, pa je velik dio svojih obaveza prilagodio i predavanjima što ih je držao u bogoslovnom sjemeništu. Osim bogoslovnog nauka koji je predavao u sjemeništu, Fiamin je neko vrijeme bio i učitelj hrvatskog jezika u gimnaziji te profesor metodike i staroslavenskog jezika u sjemeništu, ${ }^{24}$ čime je zaslužio još veće poštovanje i divljenje staroga senjskog biskupa Mirka Ožegovića.

Za bečkih dana te za kasnijega svećeničkog života u Senju Fiamin je ostao u kontaktu sa svojim učiteljem Kurelcem, s kojim je izmjenjivao pisma o životu, pozivu i svakodnevici. Iz tih je pisama moguće razaznati kako su ga tijekom službovanja u Senju mučili zavist i nerazumijevanje njegovih najbližih, dok je Kurelac na njegove jadikovke počesto odgovarao s empatijom dajući mu brojne savjete ne bi li olakšao Fiaminove duševne nemire i krize. ${ }^{25}$

Zahvaljujući svojim osobitim svećeničkim sposobnostima, ali i pedagoškim znanjima, Fiamin veoma rano postaje kanonikom Riječkog zbornog Kaptola (1862.) i župnikom u Rijeci (1863.), gdje je ostao do kraja svojega života. Došavši u Rijeku, napokon se uz svećeničku praksu i duhovno djelovanje mogao posvetiti i aktivnijem javnom društvenom djelovanju. Njegova služba, ali i reputacija koju je stekao tijekom službovanja u Senju pružile su mu mogućnost da dio svoje energije stavi u službu naroda i grada iz kojega je potekao i prema kojima je osjećao određenu dužnost. U lipnju 1877. biskup Juraj Posilović ustoličio ga je za kapitularnoga predstojnika i arhiđakona riječke zborne crkve. ${ }^{26}$

Devetnaesto stoljeće $u$ tadašnjoj Rijeci bilo je razdoblje brojnih političkih i društvenih promjena, a polariziranost društva mogla se osjetiti u gotovo svim

22 I. Lukežić, Ivan Fiamin, n. dj., str. 37.

23 Sjemenište je osnovao kardinal Petar Pázmány za mađarske klerike. Kvetoslava Kučerova, Trnavsko sveučilište i njegovo mjesto u kulturnim kontaktima s Hrvatima, Spomenica Ljube Bobana, Zagreb, 1996., str. 113-114.

24 I. Lukežić, Ivan Fiamin, str. 16.

25 J. Martinolić, n. dj., str. 1.

26 I. Lukežić, Ivan Fiamin, n. dj., str. 57. 
dijelovima života. U takvim su okolnostima jedino mogle opstati osobe koje su bile tolerantne, iskrene i humane, a sve te odlike resile su upravo Fiamina, koji je svojim postupcima i nesebičnim ponašanjem zaslužio poštovanje svih društvenih i političkih skupina. Osim toga, Fiamin je bio visoko obrazovana osoba koja je fluidno govorila hrvatski, njemački, francuski i talijanski jezik, a bio je i dobar poznavatelj strane literature, koju će prevoditi i tako je učiniti dostupnom hrvatskome stanovništvu. ${ }^{27}$

Dolaskom u Rijeku proširio se spektar njegovih mogućnosti; tako se na poticaj svojega učitelja Kurelca počeo baviti i književnim radom, u kojemu će biti vidljiv utjecaj i nazori spomenute Kurelčeve riječke filološke škole. Književnoj javnosti predstavio se poučnom pripovijesti Obitelj ili odhranjivanje (Vienac, 1869.), dok je nekolicinu prosvjetnih, književnih i religioznih napisa i prijevoda objavio u različitim onovremenim novinama i časopisima: Jurina i Franina (Opatija, 1926.), Zatočnik (Sisak, 1870.), Hrvatsko selo (Zagreb, 1944.). Osim prijevoda (Mladić upućen na dobrotu i rad (1868.), Poštenjak (1869.), Dobro i zlo (1874.)) i kraćih napisa, Fiamin je napisao i objavio poučnu knjižicu Radnja čovjeku dužnost $i$ blagodat koja je bila namijenjena mladeži i široj publici. ${ }^{28}$

Inače, Fiamin je izrazito njegovao i ljubio hrvatski jezik te je često isticao kako je narodni jezik prvi koji bi svi trebali naučiti i razumjeti. Svojim prijevodima i napisima želio je omogućiti široj publici čitanje i vježbanje hrvatskog jezika, a svoje slobodno vrijeme najradije je provodio u čitaonicama. Bio je potpredsjednik, a od 1881. godine i predsjednik hrvatske čitaonice u Rijeci ${ }^{29}$ te prvi predsjednik hrvatske čitaonice Zora u Opatiji pri čijem je otvaranju održao vatreni govor: „Svečanost, koju danas slavimo sa otvorenjem ove hrvatske čitaonice 'Zore' u Opatiji, čini bez dvojba znamenit dogodjaj u povijesti istarskih Hrvata (...) Primjerom nam je 'Hrvatska čitaonica' u starodrevnom gradu Kastvu. Ognjište je to, koje je širom pokrajine porazbacalo hrvatske sviesti žarke zrake. Takva zraka pade sretno i na ovaj val sinjega mora, u našu divnu Opatiju, ter tu požrtvovnim patrijotizmom nekolicine samo domaćih muževa došli smo do gradnje ovih prostorijah i do oživotvorenja ovog čitaoničkog društva 'Zore', koju ovim svečano proglašujem otvorenom." ${ }^{\prime 30}$

\footnotetext{
M. Grlović, n. dj., str. 124.

28 I. Lukežić, Ivan Fiamin, n. dj., str. 65.

29 Isto, str. 68.

30 Amir Muzur, Opatijska Zora: Priča o jednom simbolu, Opatija, 1997., str. 17.
} 
Osim djelovanja u hrvatskim čitaonicama, školskim odborima i svećeničkom službovanju, Fiamin je često pokazivao i humanitarnu crtu, pri čemu je, neovisno o političkoj i religijskoj orijentaciji, pomagao potrebitima i nemoćnima svoje Rijeke, ali i naseljima u njezinoj bližoj okolici. Tako je u Rijeci otvorio mnogo objekata javne namjene, poput sirotišta, škola i javnoga kupališta. ${ }^{31}$ Preminuo je 25. travnja 1890., a do kraja života ostao je aktivan u javnom životu zaduživši tadašnju Rijeku svojim djelovanjem i obilježivši jedno razdoblje riječke povijesti. Na njegovu pogrebu na riječkome groblju Kozala, prema napisima u ediciji Bilanca, sudjelovalo je oko tri i pol tisuće ljudi, što je nedvojbeno dokaz ugleda koji je ondje uživao. ${ }^{32}$

\section{Korespondencija}

Fiaminova korespondencija upućena Račkome sastoji se od dvadeset i četiri pisma i pohranjena je u Arhivu Hrvatske akademije znanosti i umjetnosti. Započinje 1861. i traje do 1889. godine, i to s različitim intenzitetom. Prve dvije godine Fiamin Račkome piše iz Senja, a potom iz Rijeke. Korespondencija je najintenzivnija u periodu između 1869. i 1871. godine, kada je Fiamin sastavio ukupno trinaest pisama. Njihove sadržaje tematski možemo grupirati u više cjelina: Fiaminovo književno djelovanje, svećenička imenovanja, školska pitanja, knjige, molba za učenike i društvena djelatnost.

Valja istaknuti da je jedan od poticatelja Fiaminova nakladništva bio i biskup Juraj Dobrila. Tako se, došavši u tadašnju Rijeku, Fiamin s njime dopisivao, a u jednome od pisama Dobrila mu piše: „Dosta je zlo po naš narod; treba ga budit pučkom knjigom, koja će za nj doći kad tad."33 I sam Dobrila držao se toga inicirajući izdavanje dva godišta Kalendara Istran ${ }^{34}$ te pokrenuvši 1870. list Naša sloga. ${ }^{35}$ Dobriline sugestije kod Fiamina su imale velik odjek, s obzirom na njegovu nakladničku djelatnost, koja je uslijedila u iduća dva desetljeća. Fiamin će

31 I. Lukežić, Ivan Fiamin, n. dj., str. 74.

32 Il funerale di Monsignor Fiamin, Bilancia, 96, 28. 4. 1890., str. 1.

33 Božo Milanović, Hrvatski narodni preporod u Istri, 1, Pazin, 1967., str. 241.

34 Maja Polić, Petar Strčić, Kalendar "Istran” 1869. i 1870. godine. Prvo glasilo Hrvata Istre i Kvarnerskih otoka, Pazin - Rijeka, 2015.

35 Nevio Šetić, O povezanosti Istre s ostalim hrvatskim zemljama. Naša sloga 1870. - 1915., Zagreb, 2005.; Petar Strčić, Nekoliko podataka o otoku Krku i "Našoj Slogi” 1870. godine, Krčki zbornik, 1, Krk, 1970., str. str. 351-369; Ines Srdoč Konestra, Prolegomena proučavanju feljtonistike u listu „Naša sloga", Fluminensia, IV, 1, Rijeka, 1992., str. 39-44; Maja Polić, Prilog poznavanju preporodnoga lista "Naša sloga" (1870.-1915.), Riječki teološki časopis, 18, 1, Rijeka, 2010., str. 267-290. 
se $\mathrm{u}$ tome periodu naći „na stotinu tegob da bude narodno i razumljivo pisano, čisto po našu, što bi i neuk razumio" ${ }^{36}$. Kao što je vidljivo iz pisama upućenih Račkome, Fiamin kao šprancu za prijevode nije mogao koristiti slične prijevode jer ih tada još nije bilo, a nije mu uvijek ni bilo moguće pronaći adekvatne inačice u hrvatskome jeziku koje bi odgovarale onima na jeziku s kojega je prevodio. U konačnici, ozbiljan je zadatak bio odabrati autore čiji će prijevodi djela naići na najbolji odjek u hrvatskome puku. U počecima se Fiamin odlučio za djela Cesara Cantùa, jednoga od najproduktivnijih pisaca talijanskoga XIX. stoljeća. ${ }^{37}$ Naime, Cantù je objavio više od pet stotina radova, uključujući i više knjiga te nekoliko prijevoda u Italiji, na području Europe te u SAD-u. Njegova produktivnost, smatra M. Deanović, priskrbila mu je glas popularizatora „smjelih historijskih sinteza" i romantičnoga publicista „poučnih knjižica za široke slojeve i omladinu", što je bilo u skladu s Fiaminovim odabirom publike kojoj je namijenio svoja djela. ${ }^{38}$ Još je jedan razlog zbog kojega je Fiamin odabrao njegova djela. Cantùa je privlačio slavenski svijet, stoga je u južnim Slavenima vidio predstavnike populacije koju je imao želju upoznati tražeći u povijesti elemente moralnog i političkog odgoja te praktičnu pouku. ${ }^{39} \mathrm{Uz}$ to, Fiamin je izabrao prijevode Cantùovih djela i iz razloga što je ovaj bio poznat riječkoj čitateljskoj publici: naime, 1868. godine u knjižari Stabilimenta Tipo-litografica Fiumana nudilo se petnaest Cantùovih naslova po prigodnim cijenama. ${ }^{40}$

Naklonost Račkoga Fiaminu vidi se iz njegove korespondencije s Ivanom Kukuljevićem Sakcinskim. Naime, iz Senja će Rački Kukuljeviću uputiti više pisama, a u nekoliko njih prenijet će mu i pozdrave nekolicine likova, pa tako i Ivana Fiamina ${ }^{41}$, kojega spominje kao „vrloga”, ${ }^{42}$ a može se naslutiti i da je on čovjek od povjerenja F. Račkoga, jer mu Rački javlja kako će sve ili gotovo sve njegove knjige rasprodati, a višak je dao Fiaminu u Senju, koji će ga dalje izvijestiti kada dođe vrijeme. ${ }^{43} \mathrm{U}$ jednome od idućih pisama navodi kako je ostatak Kukuljevi-

\footnotetext{
36 Mirko Deanović, Cesare Cantù u odnosu prema Hrvatima, Rad JAZU, Zagreb, 1951., str. 46.

37 Isto, str. 16.

38 Isto, str. 17, 18.

39 Isto, str. 17.

40 Catalogo di libri vendibili, Bilanca, 52, 26. 12. 1868., str. 2.

41 Tadija Smičiklas, Život i djela dra Franje Račkoga, Djela Jugoslavenske akademije znanosti i umjetnosti, knj. XV., Zagreb, 1895. U Senju, 30. 4. 1857. (str. 170); U Senju, 14. 6. 1857. (str. 174); U Senju, 12. 10. 1860. (str. 219).

42 U Senju, 1. 7. 1857. (str. 175).

${ }^{43}$ U Fužini, 5. 10. 1857. (str. 178).
} 
ćevih knjiga dao Vinku Pacelu u Rijeci, a on će novac koji za njih dobije poslati Fiaminu u Senj, a Fiamin će ih potom poslati Kukuljeviću. ${ }^{44}$ U pismu u kojemu pravi računicu o izručenim mu te prodanim knjigama spominje kako je njihov ostatak dao Pacelu u Rijeci te Fiaminu i Potočnjaku u Senju kako bi ih prodali. ${ }^{45}$

\section{Fiaminovo književno djelovanje}

Rezultat napora biskupa J. Dobrile i zasigurno F. Kurelca te prilika koje su u to doba vladale bila je Fiaminova najava Račkome s početka 1861. godine kako će uza sve obveze koje ima, bilo one prijatne, bilo one neprijatne, napisati i objaviti nešto na hrvatskome jeziku. ${ }^{46}$ Ističe kako to neće biti ništa revolucionarno već jedan manji prilog. Planirao je i prevesti knjižicu Dei doveri degli uomini autora Silvia Pellica, ${ }^{47}$ koji je, kao i Cantù, pripadao grupi Manzonia, odnosno romantika „,s istaknutom oslobodilačkom tendencijom, koji obrađuju građu iz domaće povijesti" 48 . Ipak, prvi odabir bila su Cantùova djela, koja su, kako ističe M. Deanović, naišla na odjek najprije u tadašnjoj Rijeci na početku ugarskoga perioda koji je uslijedio nakon potpisivanja Hrvatsko-ugarske nagodbe 1868. godine.

Fiamin se i prije prevođenja unaprijed ogradio od eventualnih jezičnih zavrzlama: „Čuvao sam se, što bolje mogoh nespretno kovanih riečij da jezik bude što čistiji i razumljiviji te ju uzmogne svatko čitati." Račkoga pri tome doživljava kao veliki autoritet čijemu će se sudu u potpunosti pokoriti, te bi se knjižicu moglo plasirati ako se Račkome svidi. Što konkretno s njom valja činiti, ostavlja Račkome na volju: ako ocijeni da su njegovi prijevodi kvalitetni, bit će mu to poticaj da se uhvati u koštac s daljnjim prijevodima, te će prevesti „,... još bolju i koristniju knjižicu, gde se narodu pripoveda o korisnih stvarih po svetu, o vedah i umetnostih načinom posve prostim i razumljivim." O kojoj se knjižici radilo, ne navodi. ${ }^{49} \mathrm{O}$ tome je razgovarao i s biskupom Vjenceslavom Šoićem, ${ }^{50}$ ali je

$44 \quad$ U Rimu, 26. 11. 1857. (str. 182).

45 U Rimu, 3. 2. 1860. (str. 213).

46 Senj, 15. 1. 1861., AHAZU, XII, A, 155/1.

47 Silvio Pellico, Dei doveri degli uomini, Milano, 1873.

48 M. Deanović, n. dj., str. 43.

49 Pretpostavljamo da je riječ o prijevodu knjige Cesarea Cantùa, Mladić upućen na dobrotu, nauku $i$ rad, Rijeka, 1868.

50 O Vjenceslavu Šoliću usp. Maja Polić, Bakranin dr. Vjenceslav Šoić, biskup Senjsko-modruške biskupije, Bakarski zbornik, 11, Rijeka, 2007., str. 40-47; Petar Strčić, Maja Polić, Franjo Rački i Josip Juraj Strossmayer o senjskome biskupu Vjenceslavu Šoiću i kanoniku/znanstveniku Ivanu Črnčiću, Radovi zavoda za znanstveni rad - Varaždin, 19, Varaždin, 2008., str. 131-149. 
odlučio da bi, iako djelo ne bi obuhvatilo više od pet tiskanih araka, trošak bio prevelik, pa se cijela akcija dovodi u pitanje. Unatoč tome što je riječ o prijevodu dobre knjižice, sredstva bi se za to vrlo teško prikupila. No, Fiamina to nije obeshrabrilo već je istaknuo kako je dobre volje, a tome pridonose i poticaj i podrška samoga Račkoga.

Koncem ožujka 1861. „listovnom poštom” dostavlja mu gotov prijevod, i to kako bi ga Rački primio prije nego što ode u Đakovo. ${ }^{51}$ Fiamin se unaprijed ograđuje od izgleda samoga rukopisa: isti nije prepisan „kako bi se pristojalo" da ga se može staviti „pred onolika čoveka dojde što ga je Preuzvišeni g. Strossmayer", stoga moli Račkoga da ga ispriča kod Strossmayera. Rukopis je, dodaje, iz izvornika prepisan na brzu ruku, sam je prijevod križan i ispravljan i, unatoč tome, na njemu još valja raditi ističući kako jednom treba stati i dati ga $u$ tisak. Po Fiaminovu sudu, prijevod ima felera, a to su nedostatak konjunkcija u hrvatskome jeziku, dok se nedostatku vokabulara može doskočiti opisivanjem. Ako se prijevod Račkome i Strossmayeru svidi i ako budu smatrali da je dostojan da bude tiskan, to će ga ohrabriti da krene u daljnje prevođenje. No, ako spomenuta dvojica ocijene da rukopis nije adekvatan za objavu, to će prihvatiti, a Račkoga moli da mu rukopis o Fiaminovu trošku natrag vrati, a on će ga što prije sakriti pred bijelim svijetom. Ističe kako je Račkome poslao prijevod zbog velike sumnje u rezultat svojega napora; da tome nije tako, tiskao bi ga sam, bez konzultacija s Račkim. On sam prihvatit će svaki njegov komentar veseleći se što će Rački naći vremena makar i za kratki komentar.

Godine 1869. Fiamin je pripremao knjigu Radnja čovjeku dužnost i blagodat te moli Račkoga da mu istakne dva do tri primjera ljudi iz hrvatske povijesti, koji su „„... od priprosta rada", poput orača, kopača, zanatlija i sl., te koji su zahvaljujući svojim vještinama dogurali „do njeke znamenitosti”, poput vojvoda, biskupa ili bilo kojeg drugog dostojanstvenika. ${ }^{52}$ Navedeno mu je potrebno za knjižicu koju priprema, a o kojoj je Račkome već govorio. Njezin rukopis „izim dviuh glav" poslao je Dežmanu, pa će i od njega dobiti primjere. Navodi kako mu je izvjesni Bakotić obećao dati primjere ljudi niskoga staleža koji su se istaknuli izumima ili popravljanjem i unapređivanjem "spravah i orudja, makinah i td." Pretpostavlja kako nema nade da će se navedeni primjeri ticati naših ljudi „,jer u tom zaostadosmo", ali će za ono za što njemu treba i strani primjeri dobro doći, jer „Čovjek je čovjek, gdje mu drugo bio i koga bio naroda

$51 \quad$ Senj, 24. 3. 1861., AHAZU, XII, A, 155/2.

52 Rijeka, 1. 10. 1869., AHAZU, XII, A, 155/10. 
i poroda." Nada se da Račkome neće biti teško „ovu veliku ljubav” učiniti, odnosno ispuniti Fiaminov zahtjev. Inače, Fiamin je smatrao kako nečije podrijetlo ne treba imati reperkusije na postignuća. Među primjerima pojedinaca koji su mnogo postigli, a skromnoga su roda, navodi papu Siksta V., Benjamina Franklina, Abrahama Lincolna, Kristofora Kolumba, a od domaćih kardinala Tomu Bakača te banove Ivana Horvata i Matka Talovca. ${ }^{53}$ Račkoga moli i da, ako u svojoj knjižnici pronađe knjižicu namijenjenu „neučenim”, neka mu je dostavi. Dodaje kako je od već prevedenih knjiga, spomenutih Mladića i Pošte$n j a k a^{54}$, namjeravao „po jedan ljepši egzemplar” poslati biskupu Strossmayeru, no, zbog troškova, moli Račkoga ne bi li njemu iste mogao poslati, pa da ih on onda preda Strossmayeru. Žalio mu se kako je svojemu biskupu Šoiću pokazao posljednju prevedenu knjigu, s namjerom da je preporuči kleru. Vjerujući da će biskup Šoić udovoljiti njegovoj molbi, drugima svoju knjigu nije preporučivao. Budući da ga je Šoić ostavio na cjedilu te se knjiga razdijelila kupcima, Fiaminu je ostalo još četiristo ili čak petsto komada, stoga moli Račkoga za pomoć: „Ako mi vi gore nepojdete na ruku, ja duhom klonuh uza štetu, što bi imao pišuć ovake knjižice, a ja mislim da se naša knjiga i sud prostiju čeljad širiti ima, želimoli si napriedka. (...) nu kako rekoh pomozite kako znate, ja koristi skroz nikakve neištem, ali uz ovu kukavštinu ni štete neprebolih." Istaknuo je kako ima želje i volje i dalje pisati i, unatoč tome što prva djela možda i ne vrijede mnogo, nada se da će ona iduća biti bolja, „,jer mi i pero brže leti, koje mi izprva tvrdo u ruki bilo i sporo se micalo". Rački je očito vrlo brzo reagirao, pa mu Fiamin srdačno zahvaljuje na pomoći. ${ }^{55}$ Zahvaljuje mu i na bodrenju oko tiska knjižice, ali - sumnjajući u sebe - pita ga je li knjižica uopće vrijedna tiska. Pomalo zabrinuto konstatira kako od Račkoga još nije dobio odgovor na prije dva mjeseca poslani mu rukopis. Doduše, knjižica još nije dovršena i valja još u predani tekst unijeti neke dopune te još dva nova poglavlja. Cijeli posao oko prijevoda Fiamina je očito obeshrabrio, pa izražava sumnju ima li sve to uopće smisla: „ali čemu na poštu trošiti, nejmam li stanovite nade, da joj se tamo najde načina da svjetlo ugleda?" Stoga moli Račkoga za savjet oko eventualne prenumeracije. Razmišlja kako bi tu "pučku” knjižicu mogao poslati svećenicima u Sv. Jerolimu u Rimu, ali izražava bojazan „da ako gdjekoja rieč u njoj nije u njihovu leksiku ili po dogmi njihove gramatike i sintakse, posta-

53 Radnja čovjeku dužnost i blagodat, n. dj, str. 22 i dalje.

54 Riječ je o prijevodu knjige Cesarea Cantùa, Poštenjak iliti Pravice i dužnosti. Po 18. milanskom izd. God. 1861. piscem pregledanom, Rijeka, 1869.

55 Rijeka, o Martinji 1869., AHAZU, XII, A, 155/11. 
više ju u index?". ${ }^{56}$ Dodaje kako mu se čini da kod nas, povrh svega, postoji i književna nesnošljivost, iako smatra da se u Primorju, što se jezika tiče, njegov jezik pisanja odobrava.

$\mathrm{U}$ istome pismu Fiamin Račkome nudi dva do tri djela, $\mathrm{u}$ tom času tek isplanirana, ali se nada da će ih malo pomalo i završiti, napominjući kako ga situacija bode i nuka da što više radi. ${ }^{57}$ Iz toga proizlazi da je u tome razdoblju Fiamin bio veoma vrijedan. Dodaje da mu se najviše dopada ideja maloga hrvatskoga Plutarha, jer želi ostati „pri pučkom”, ne želeći zbog manjka vremena ulaziti u znanost. No, i za odabrani pristup treba imati materijala, kojega za tu nakanu nema. Stoga predlaže Račkome da mu namakne/osigura materijal, a on će ga onda „onako po pučku” realizirati, dodajući: „Ta djelit nam je posao, hoće li što iz nas biti, jer, rada je mnogo, a rabotnikov malo!" Prije zaključka još jednom pita Račkoga hoće li biti štogod od poslane knjižice ili da materijal uzme natrag, pa ga ispravi i doda što je zamislio.

U idućemu pismu dostavlja mu ono što je u spomenutome rukopisu nedostajalo, odnosno jedno poglavlje i dodatke. ${ }^{58}$ Napominje kako je obilježio gdje se što treba dodati te moli Račkoga da priloge uklopi gdje treba. Ponovno ističe kako ne piše „(...) ni za filologe ni učene ljude, već za puk, to jest većinu, a da radi koje forme uzkratim puku, što je njemu namjenjeno bilo početkom, to bi od mene ponajmanje tvrdoglavost bila." Na temelju dotadašnjega iskustva s pukom, smatra da je bitna razumljivost, čistoća jezika i ritam dodajući kako ne postavlja nikakve uvjete već samo moli da se knjiga tiska u formatu u kojem su tiskane knjige Mladić i Poštenjak jer je dobio informaciju da je taj format ljudima drag, a i knjige sličnoga sadržaja također se tiskaju u tom formatu. Nadalje, moli Račkoga da se knjiga korektno tiska, s obzirom na to da je imao neugodno iskustvo s listom Vijenac, u koji je poslao neki tekst, pa je zbog nerazumijevanja pisma ili nekog drugog razloga došlo do promjena rukopisa: „pometali mi aše i kratki perfekt, gdje mu po mom osvjedočenju mjesta nebilo i koješta drugo." Dodaje kako je $u$ društvenome interesu da se takve pogreške ne čine, jer ih je onda u puku bilo teško ispraviti. Ističe kako je već ranije Račkome i Dežmanu napisao da od knjige ne traži nikakve koristi, čak ni dvadesetak primjeraka za svoje prijatelje. Jedino bi bio zahvalan ,... kad bi naljepšoj hartiji bio jedan exemplar za Cezara Cantùa, koji mi se opetovano vrlo prijazan izkazao, a pak vredi i

\footnotetext{
56 Navedenu knjigu Radnja čovjeku dužnost i blagodat tiskalo je Društvo sv. Jeronima

57 Rijeka, o Martinji 1869., AHAZU, XII, A, 155/11.

58 Rijeka, 28. 11. 1869., AHAZU, XII, A, 155/12.
} 
kao prijatelj našemu narodu, kako u svom pismu mi dokaza." Pojašnjava kako bi u poglavlje koje je Račkome naknadno dostavio upisao još neke primjere, ali kako mu do tada obećani primjeri još nisu dostavljeni, iste će eventualno ubaciti ako do njega stignu za jedan do dva dana. Ako ne, rukopis može u tisak i bez njih, jer je i kroz dva navedena primjera dokazao ono što je namjeravao. ${ }^{59}$ Javlja i kako će uvažiti opasku F. Račkoga u predgovoru.

Fiamin je očito i dalje vršio istraživanja jer koncem prosinca Račkome dostavlja još neke primjere. ${ }^{60}$ Napominje kako je sličnih primjera i ranije bilo, ali „s druge ruke uzetih”, stoga moli Račkoga da, ako knjiga nije štampana, dodatak preda gdje treba. Ističe kako je s tim dodacima knjiga konačno gotova te kako Račkoga, svjestan njegove zauzetosti, neće više uzmemiravati: „(...) znam bo cieniti i vrieme i poslove tvoje toli pa kao blagoslovne, leh te molju još ovu ljubezan, pošto neznam na koga bi odpravio a da se negubi."

Kako proizlazi iz korespondencije, početkom 1870. godine postojao je plan pisanja pučke knjižice „o našem narodu”, stoga Račkome predlaže sastanak nekolicine osoba koje su „u ovih neizvjestnih okolnostih u obće za hrvatstvo ovdje", a koje bi, na prijedlog Račkoga, mogle sudjelovati u pisanju. ${ }^{61}$ Fiamin veoma rado prihvaća predloženi zadatak, ali se još neko vrijeme ne može uhvatiti posla jer radi na djelu za koje ocjenjuje da „nije baš pučko nego tiče se pučke prosvjete", a radni mu je naslov O pučkoj prosvjeti, njekoliko misli. Na pisanje toga djela Fiamina je ponukala činjenica da se drugdje tiskaju knjige "pod imenom pučkih koje da se nasljeduju ili prevode u nas”, a po njegovu sudu „,za puk nebi ni bile jer nije toli napredan". Dodaje da će tekst, ukoliko bude ispao kako planira, poslati Račkome kako bi prosudio treba li biti tiskan kao knjižno izdanje ili u listu Vijenac kroz više članaka. ${ }^{62}$ Smatra da knjige ovoga tipa za cilj imaju „odgojenje puka”, a u tome procesu treba biti nekakvoga reda i pravila, kako bi se objavljivanje uspješno obavilo. No, za Fiamina problem predstavlja sporost $u$ pisanju, koju polako nadvladava, te se na taj način unaprijed ispričava što rukopis neće tako brzo ugledati svjetlo dana.

U ožujku 1870. godine Fiamin javlja Račkome kako je započeo raditi na djelu na koje ga je on sam potaknuo. ${ }^{63}$ Pretpostavljamo da je riječ o rukopisu spome-

\footnotetext{
59 Isto.

60 Rijeka, 29. 12. 1869., AHAZU, XII, A, 155/13.

61 Rijeka, 15. 1. 1870., AHAZU, XII, A, 155/14.

62 Rukopis je objavljen u listu Vijenac u nekoliko nastavaka.

63 Rijeka, 11. 3. 1870., AHAZU, XII, A, 155/15.
} 
nute knjižice „o našem narodu”. Za tu svrhu nabavio si je i „slovnik naučnij”, ali mu nedostaju podaci za Srbe i Slovence. Budući da si je iz Praga naručio knjigu o slavenskoj povijesti, ali je ista razdijeljena, moli Račkoga da mu je dostavi ako je posjeduje. Ističe kako i u ovoj prigodi želi pisati popularno s namjerom da knjižica dopre do što širega broja čitatelja, $i$ to kako do običnoga puka, tako i do riječkih intelektualaca. Iznosi i plan pisanja: krenut će od pisane riječi bitne za zajednicu, obitelj i širu rodbinu sve do plemena te će nastojati izbjeći da u rukopis uvrsti "suhoparne stvari” već samo ono što bi čitatelje moglo zanimati i ugoditi im. Unaprijed ističe: „(...) dočim se kod nas jugovićev budem podulje zadržao i dokazivao da je to jedan narod, i kojim putem sjedinili se drugi narodi, ob ostalih slovinjanih samo in nješto spomenuti; a imam zato više razloga, a najpreči je onaj, da mi jugovići možemo i politika je da jedno budemo i u knjizi, čim te nade u cielu slovinstvu nejma." Na kraju pisma sažimlje svoje molbe: ponajprije moli da mu se dostavi djelo koje do tada nije mogao nabaviti, a potom moli savjet na koji da način djelo tiska sugerirajući da bi nakladnik moglo biti Družtvo sv. Jeronima. Dodaje kako je djelo još u nastajanju, ali da je već pri kraju, pa već sada o tome valja voditi računa. Svoj upit završava pomalo rezignirano: „Nevolja je što se ovdje za knjige nemože čovjek pomoći." Rački je vrlo brzo reagirao, stoga mu Fiamin toplo zahvaljuje na poslanome mu djelu. ${ }^{64}$ Uz navedeno, Rački mu je u svojemu pismu očito sugerirao da konzultira i djelo Obraza svjeta slovanskega, na što mu Fiamin odgovara kako je do navedena djela veoma teško doći. Upit je poslao u Prag, no sreća ga ni ovoga puta nije poslužila. Stoga moli Račkoga da mu ide na ruku te da mu i tu knjigu što prije dostavi. Unaprijed mu se ispričava što će mu se još obraćati za pomoć ako mu bude bilo potrebno dodajući kako bi bilo bolje kada bi bili bliže, pa bi mu bilo lakše Račkoga pitati za savjet i koristiti se njegovom knjižnicom, za razliku od situacije u tadašnjoj Rijeci, gdje se nema kome obratiti. Izražava pritom i žaljenje zbog bremena koje nosi i koje mu svakim danom postaje sve teže, a to je djelovanje u župi, gdje mu birokracija ne dozvoljava da se ozbiljnije posveti književnome djelovanju.

Na početku pisma iz studenoga 1870. navodi kako mu je Rački jednom prigodom rekao neka se ne brine o načinu na koji će njegove knjižice biti tiskane nego da ih samo piše, a Rački i ljudi uz njega pobrinut će se da iste ugledaju svjetlo dana. ${ }^{65}$ Stoga mu se javlja završivši ",knjižicu iz talijanskoga" naslovljenu Dobro i zlo. Knjiga za svakoga. Talijanski napisao dr. Pavao Mantegazza učitelj na ve-

64 Rijeka, 23. 3. 1870., AHAZU, XII, A, 155/16.

${ }_{65}$ Rijeka, 7. 11. 1870., AHAZU, XII, A, 155/17. 
likih školah u Paviji. Hrvatski priredio Ivan Fiamin. ${ }^{66}$ Pa iako je knjiga "popularna”, Fiamina zanima bi li za nju bilo zainteresirano Društvo sv. Jeronima. Knjiga je, ističe, izvorno namijenjena ",za srednju klasu i mladež - učeću”, a u Italiji je bila vrlo cijenjena i nagrađivana. Dodaje kako se pri prevođenju prilagodio svemu što se „njekim načinom i običajem uzakonilo u jeziku”, a namjera mu je bila da, koliko je uzmogao, jezik bude „liep i ugodan”. Ne bi li to postigao, odrekao se „kojegod mušice, što mi u prvih knjigah bila." Ako se Rački slaže, Fiamin bi mu poslao prijevod čim ga prepiše na čisto, a Račkoga moli da učini ono najbolje što zna. Dodaje kako se odriče i najmanje materijalne koristi, a od Račkoga moli da prikupi 100 forinti, koliko će biti potrebno za tisak, s obzirom na to da će knjiga imati do najviše sedam araka običnoga formata. Ističe kako se trudio što bolje je srediti, a Rački, ako ocijeni da ju je vrijedno tiskati, neka mu otpiše tek s dva retka, pa će mu je Fiamin poslati. Na kraju pisma ispričava mu se što mu dosađuje objašnjavajući: „,... počesto i grabim dragocedno po naš rod vrieme tvoje, ali pouzdanijega nejmam do tebe u takvoj stvari." Iako je djelo bilo pri kraju, Fiamin je već imao ideje za novo djelo; napravio je plan, ali o detaljima će mu pisati drugom prigodom.

Koncem studenoga 1870. godine Fiamin Račkome šalje „gotova ponudjena diela". ${ }^{67}$ Ako ne budu za puk, kome ih je Društvo sv. Jerolima namijenilo, moglo bi se ponuditi „nješto inteligentnijoj klasi”. Material je, po njegovu sudu, dobar, a forma je „nješto finija”. U knjižici o kojoj sanja, naći će se i dijalozi o kojekakvim znanja vrijednim temama za naš puk. Dodaje kako se u okviru župnoga djelovanja mora baviti i materijalnim stvarima, zbog čega izražava žaljenje jer je to, po njegovu sudu, posao za policiju i magistrat. Da nema toga, mogao bi uspješnije djelovati, a ovako tek mali dio vremena može posvetiti književnome radu.

U siječnju 1871. godine Fiamin ponovno moli Račkoga informacije oko posla dodajući kako ga ne želi gnjaviti, ali da može razumjeti njegovu zabrinutost. ${ }^{68}$ Naime, 28. studenoga prethodne godine poslao je s potvrdom primitka spomenuto djelo Dobro i zlo, no do njega nije došla vijest da ga je Rački uopće i primio. Dodaje da će ga, ako Rački smatra da nije za objavljivanje, povući. Ističe kako je izvornik bio puno hvaljen, ali - „uz kurvanjluk” što je nastao u višim krugovima - smatra da nije zgodno držati se dobroga običaja u našem narodu. Iako Cantù, čije je djelo preveo, ima nešto slično, Fiamin smatra da se "tako krasne istine"

\footnotetext{
66 Knjižica je tiskana u Primorskoj tiskari u Kraljevici 1874. godine.

67 Rijeka, 28. 11. 1870., AHAZU, XII, A, 155/18.

68 Rijeka, 13. 1. 1871., AHAZU, XII, A, 155/19.
} 
poput onih u knjizi P. Mantegazza ne mogu dosta ponavljati, tim više što je upoznat i s time da "nepokvarena čeljad to rado sluša, ako se baš u nas još i nečita mnogo". Moli Račkoga da mu s dva retka otpiše je li primio rukopis te ima li rukopis nekih izgleda da se objavi. Dodaje kako upravo radi na opširnijem djelu, u kojemu će biti svega pomalo što bi moglo puku mnogo toga razjasniti, a ujedno i oplemeniti sudce, oblikom najzgodnijim za takvu čeljad kojemu nisu svojstveni ni pripovijest ni dijalog. Imajući povjerenja u Račkoga, ponovno mu piše neka s njegovom knjižicom radi najbolje što zna. ${ }^{69}$ On sam trudi se na novome djelu, a kada će ono biti gotovo, ne može mu još reći.

\section{Svećenička imenovanja}

Saznavši da je Rački u Beču, Fiamin mu se javlja s posebnom molbom; naime, iz Senja je prije više od mjesec dana u Beč poslan prijedlog kandidata za Riječku kanoniju. ${ }^{70}$ Do Fiamina je došla vijest da je prvi na listi predloženih, a to je čuo i od starog i od mladog biskupa ${ }^{71}$ koji žele da se stvar što prije riješi. Živo zainteresiran za rješavanje toga pitanja, moli Račkoga da mu, ako može doći do podataka, javi rezultat izbora. ${ }^{72}$ Sam Fiamin svjestan je da ga u tadašnjoj Rijeci „ni pir ni rožice nečekaju”, a i zbog same činjenice da je Hrvat, zamjerit će se Riječanima dodajući: „Al bilo kako mu drago, što da učane popu a osobito miroljubivu, i držećemu više do svoga života nego li do stotinu njihovih." Vjerujući da ima velike šanse biti izabran, dodaje kako već razmišlja na koji način djelovati na novoj dužnosti, iako, smatra, ",spravljam ražanj a zec ugori."

69 Rijeka, 9. 2. 1871., AHAZU, XII, A, 155/20.

70 Senj, 15. 5. 1862., AHAZU, XII, A, 155/3.

71 Stari je biskup Mirko Ožegović, a mladi Vjenceslav Šoić. Usp. Mile Bogović, Biskup Mirko Ožegović, Senjski zbornik, 17, Senj, 1990., str. 249-260.

72 Uzdignućem Zagrebačke biskupije na metropolitansku razinu u prosincu 1852. godine Krbavsko-modruška biskupija pripala je Zagrebačkoj nadbiskupiji. Tadašnja je Rijeka 1787. dana na upravu senjsko-modruškom biskupu. Od razdoblja jozefinizma bečki je vladar potvrđivao imenovanja crkvene vlasti. U sačuvanim internim glasilima, primjerice Okružnicama biskupskog ordinarijata Senjskoga i Modruškoga ili krbavskoga, moguće je razabrati kako je Ordinarijat po potrebi sastavljao „Natječaj za ispražnjene župe”, kao i za druga imenovanja. Odgovor je dostavljan na adresu Ordinarijata u Senju, uz naslov: „Njegovo c. kr. Apostolsko veličanstvo”. Nakon dobivanja odgovora, uslijedilo je posredno službeno imenovanje za određenu crkvenu službu, što je zbog administrativnih zavrzlama znalo i potrajati. O tome: Makso Peloza, Ivan Fiamin, Zvona, 9, Rijeka, 1977., str. 3; Mile Bogović, Povijesni koraci prema osnivanju metropolije, Riječki teološki časopis, XVII, 2, Rijeka, 2009., str. 242. 
U pismu iz listopada 1862. godine Fiamin Račkome zahvaljuje na prijateljskoj brizi jer ga je smirio i razriješio njegovu neizvjesnost oko imenovanja. ${ }^{73} \mathrm{Na}$ pominje da je dva dana nakon njegova pisma primio pismo izvjesnoga Petračića s jednakom viješću, te da će vijest za koji dan biti obznanjena u službenom listu. Ali mu je, kako je istaknuo, najvažnija podrška Račkoga, jer on je narodu koristan, te će u škole u kojima još nema pravoga reda uvesti red: „,... s čovekom tvoga uma i volje sve uspije." Za sebe je naveo kako ima volje, a njegovo djelovanje ovisit će o tome kako ga posluže um i sreća u komunikaciji s različitim ljudima, koji su, po njegovu sudu, u rasponu od prežestokih pa sve do bojažljivih, a vrijeme će pokazati njihovo pravo lice. Na njemu je, istaknuo je, držati se hrabro, a Bog je taj koji će mu dati snagu. Pa ipak izražava bojazan od prevelikoga tereta koji bi kad postane župnik pao na njegova pleća. Jednako tako, novi će zadatak svakako utjecati na pisanje knjige koje će se u znatnoj mjeri odužiti.

Početkom svibnja 1867. godine Fiamin je od Račkoga primio brzojav da dođe u Zagreb na novu dužnost o kojoj ne daje više podataka; očito se Fiamin oko toga veoma uzrujao jer je već idući dan uslijedio njegov odgovor kako bi mu bilo teško krenuti odande s obzirom na to da nije upoznat s biskupovim mišljenjem jer njegova odgovora na molbu za odlaskom još nije primio. ${ }^{74}$ Dodaje kako bez biskupove zapovijedi nitko ne bi mogao preuzeti njegov dotadašnji posao, a kao jedinoga kandidata kojega ocjenjuje adekvatnim za svojega nasljednika ističe Poglajena. ${ }^{75}$ Svjestan političke situacije, Fiamin želi razjasniti kako je, ako njegovo imenovanje bude ovisilo o jednome glasu, spreman sve žrtvovati, iako smatra da Mađari uz podršku aristokracije mogu dobiti prevagu i da neće doći do toga da presudi jedan glas. Ako bude ovisio o jednome glasu, spreman je sve žrtvovati jer odlazak bez dozvole i protivno biskupovoj volji može ga bez sumnje dovesti u nepriliku; s druge strane, ako pred riječkim zastupnicima glasa protiv mađarskih težnji, svjestan je da mu „povratka ni obstanka na Rieci nejma i onako vele zazornu i omraženu pred ovim pučanstvom", kao i da bi mu lako bilo pregaziti službu kad mu pred očima ne bi bilo da će tadašnja Rijeka možda vrlo brzo „u Magjarsko ždrielo pasti”. Ako ne bude „narodnih ljudih” u drugim djelatnostima, a u samoj bi se crkvi „talianštini” odškrinula vrata, ne bi bio problem dati samo znak „čovjeku nečvrstu” i odstraniti i ono malo narodnoga dobra što je do tada postojalo. To da Riječani nemaju pravo izabrati si župnika,

73 Senj, 7. 10. 1862., AHAZU, XII, A, 155/4.

74 Rijeka, 2. 5. 1867., AHAZU, XII, A, 155/7.

75 Giuseppe Poglajen, svećenik. O njemu usp. I. Lukežić, Ivan Fiamin, n. dj., str. 72. 
a poznato je da će se intervenirati i s drugih strana, neće stvar propasti, ali boji se da hrvatska strana nigdje u javnosti ni u samoj crkvi neće imati svojega predstavnika. No ponovno dodaje kako će, ako njegov izbor bude ovisio o jednome glasu, ta dužnost biti primarnija od svih drugih dužnosti te da je na to spreman. No, ako se situacija ne bude razvijala po tome scenariju i ako bude izgledno da će Mađari „oteti” Rijeku, bilo bi dobro da netko i na njegovu dotadašnjemu mjestu ostane. Ističe kako se "talijanski Ungarezi” prijete da će zatrti svaki narodni trag, a njihova velika želja za potalijančivanjem i otuđenjem svega hrvatskoga neće mimoići ni crkvu. To će činiti pod izlikom da talijanski jezik gotovo svi razumiju, a „zazorno" im je i ono malo što je od davnina ostalo. Crkva je, pojašnjava, „još jedino mjesto gdje se bez zazora čuje hrvatski jezik; čim se sad ni po ulicah bez priekora i insult naški razgovarati nemožeš". Međutim, i protivno nečijoj volji i uz žrtvu da se ne vrati u Rijeku, ističe kako je sklon otići na novu dužnost ako bi bilo nužno, a Račkome sugerira da sve stavi na vagu prije nego što ga osudi što ga tamo još nije.

Ističe da bi, da u Rijeci nisu "tako žalostne okolnosti", nastojao odande otići, pa čak i na nižu službu, samo da ima više vremena za književni rad. ${ }^{76}$ Navodi kako ga je pokojni kardinal Juraj Haulik namjeravao primiti i dati mu prikladnije namještenje, ali onda ga je i Šoić prevario jer ga nije na vrijeme upozorio da mu se nudi drugo mjesto, a sada je to uzalud. Sugerira Račkome neka ne misli da mu to govori iz obijesti nego da mu može vjerovati kako mu je riječka župa dojadila, ne samo iz navedenih razloga, već i zato što mu je teško $s$ tamošnjim ljudima imati posla. Rezignirano ističe da bi otišao da mu nema „njekoliko čestitih rodoljuba".

Fiaminove poslovne okolnosti vezuju se uz političke prilike. Tako u jednome od pisama progovara i o izborima poslanika za Sabor u Zagrebu, pa dodaje da - ako se budu odvijali s onakvim uspjehom kako su se odvijali izbori u ugarske sabore - bolje da ih ni nema. ${ }^{77} \mathrm{U}$ istome pismu ističe kako se u tadašnjoj Rijeci ništa novoga ne zbiva, „(...) osim ako se baba s babom ili gori od babe ljudi posvade i popravdaju".

$76 \quad$ Rijeka, 28. 11. 1870., AHAZU, XII, A, 155/18.

77 Senj, 24. 3. 1861., AHAZU, XII, A, 155/2. 


\section{3. Školska pitanja}

U svojoj korespondenciji Fiamin je Račkome pisao i o školskim problemima. Razlog tome jest funkcija školskoga nadzornika i izvjestitelja za pučke i srednje škole koju je Rački tada obavljao. ${ }^{78}$ Naime 9. veljače 1863. Rački je imenovan školskim savjetnikom i nadzornikom kod kraljevskoga dalmatinsko-hrvatsko-slavonskoga namjesničkog vijeća, a tu je funkciju obnašao do 10. travnja 1867., kada postaje predsjednik Akademije. ${ }^{79}$ Gotovo godinu i pol dana svojega mandata bavio se srednjim školama, da bi u srpnju 1864. ostao bez referade srednjega školstva, pa se posvetio pučkome školstvu. ${ }^{80}$ Tako u studenome 1863. Fiamin javlja Račkome kako će do njega stići molba „neke Ellin-

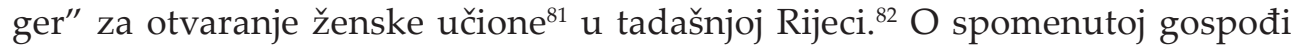
Fiamin se vrlo pozitivno očitovao: „Ona, mogu po duši reći, ima sve dobre vlastitosti, usposobljen, pokorila bi se naredbam, što s ovimi prvašnjimi težko i mukom biva." Jedina njezina negativnost jest nedovoljno poznavanje hrvatskoga jezika, ali bi ga, ako joj se pozitivno odgovori na njezin zahtjev, mogla svladati kroz godinu dana. S obzirom na to da je poznavanje hrvatskoga jezika očito bilo uvjet za otvaranje „učione”, Fiamin sugerira Račkome da spomenutu Ellinger nagovori da što prije svlada hrvatski jer je postojala mogućnost da je naslijedi netko tko nije poput nje pedagoški potkovan. Ellinger, s druge strane, „.... ima vrlo dobre i zakonite svedočbe", te će ona „,... ufano mnoge kutne zatvoriti". Uz navedenu, Fiamin je spomenuo još jednu profesoricu čije ime nije naveo, a ta je, ne bi li došla do mjesta za koje je bila zainteresirana Ellinger, namjeravala ići direktno u Zagreb po podršku. Dotična se, kako je naveo Fiamin, obratila stožerniku, ali do trenutka pisanja pisma nije dobila odgovor.

78 Antun Cuvaj, Građa za povijest školstva kraljevina Hrvatske i Slavonije od najstarijih vremena do danas, 5, Zagreb, 1910., str. 45.

79 Isto, str. 49.

80 Isto, str. 52.

81 Pod pojmom „učiona” od 1848. godine u tadašnjoj se Rijeci, kao i u Banskoj Hrvatskoj i Mađarskoj, sustav osnovnoga školstva temeljio na odredbi „Sustav početnih učionica”, kojim se organiziralo djelovanje osnovnih škola. Navedene su se dijelile na niže osnovne škole s dva razreda, odnosno trivijalne škole te više osnovne škole s četiri razreda, odnosno javne glavne učione. Nakon 1848. trivijalne su se škole u tadašnjoj Rijeci organizirale kao trorazredne pučke učione i trajale su tri godine. Anton Cuvaj, Gradja za povijest školstva, III, Zagreb, 1910., str. 346; Milivoj Čop, Riječko školstvo (1848-1918), Rijeka, 1988., str. 40, 41.

82 Rijeka, 4. 11. 1863., AHAZU, XII, A, 155/5. Na kuverti piše: „Poštovanom Gospodinu Franu Rački-u kanoniku, školskomu savetniku Vis. K. Namest. Veća zač. komorniku Nj. Svetosti, Članu više učen. Družtav u Zagrebu." 
Vezano uz školska pitanja, velik problem predstavljao je „slučaj Koričić" 83 Glavni akter bio je Herman Koričić, ${ }^{84}$ koji je od 1862. godine bio ravnajući učitelj glavne hrvatske četverorazredne učionice na Grobniku, a od školske godine 1867./1868. do 1870./1871. u gimnaziji je predavao krasopis. Problem s Koričićem Fiamin prvi put spominje u travnju 1864. izvješćujući Račkoga kako je u postupku s Koričićem ordinarijat dao zadatak Poglajenu da istražuje. Pita se i zbog čega senjski biskup brani loše gimnazijske profesore te se nada da će mu susret s Račkim dati odgovor na to pitanje. Ističe kako je očito na strani Koričića „gadna i premrska spletka rovara ovdašnjih, koji i njekoje naše zasliepiše, te bljezgaste učitelje proti Koričiću uzburkala", i to ne protiv Koričića osobno već protiv njega kao ravnatelja hrvatske škole. U međuvremenu Koričić si je „od troškovah sve namire (si) pribavio", koje je predao magistratu na njihov zahtjev. Ne imajući povjerenja u Koričića, u priču se uključio izvjesni Marković, koji je „namire” nosio računovođama kako bi provjerio navedene iznose, čime je ponovno nanio štetu Koričićevu ugledu. Problem s Koričićem vjerojatno je bio razlog posjeta F. Račkoga i poveće pratnje pučkoj školi u Grobniku 20. svibnja $1864 .{ }^{85}$

\section{Knjige}

Fiamin izvještava Račkoga kako je k njemu došao izvjesni Petračić, koji ga je zamolio da Račkome napiše zamolbu te da natukne „onomu velikomu našemu Mecenatu nebili se ožarila njegovom mislosti i senjske hrvatske knjige da se njom osladi, jer slavna Camarila čijom krivnjom bog zna nebi se sklonula da se biblioteka slovinskimi knjigami umnoži, ako bi ti za dobro našao zaprositi bi sove strane samoga Preuzvišenoga." ${ }^{16}$ Spominje i komunikaciju s izvjesnim Babićem, koji mu je kazao da će Račkome, ako on to želi, poslati njegove knjige

83 Rijeka, 17. 6. 1864., AHAZU, XII, A, 155/6.

84 Armin/Herman Koričić (Fužine, 1823. - ?, ?) Radni vijek započeo je u rodnome mjestu, a potom odlazi u Grobnik, gdje je, osim što se bavio učiteljskim poslom, djelovao i kao orguljaš. Resila ga je impulzivnost i snažan temperament, pa nakon sukoba s tamošnjim načelnikom Josipom Baćićem, zbog neredovitih isplata mjesečnih prihoda i niskoga dohotka, napušta školu i djeluje kao privatni učitelj župske škole u Rijeci, nakon čega prelazi u gimnaziju. Istaknuo se kao domoljub i borac za hrvatski narodni jezik ističući hrvatstvo radnih sredina. Koričić Armin (Herman), Irvin Lukežić, Grobnički biografski leksikon, Libellus, knjižica Thesaurus, knj. 1., Rijeka, 1994., str. 122, 123.

85 A. Cuvaj, n. dj., str. 56.

86 Senj, 24. 3. 1861., AHAZU, XII, A, 155/2. 
Ćirila ${ }^{87}$ i Slavensko pismo. ${ }^{88}$ Glede troškova slanja, Fiamin je smatrao da tu ne bi trebalo biti problema; knjige se mogu slati u sanducima bez ikakve prijave, jer prijevoz ide iz slobodne u slobodnu luku, a odande bi Rački našao prijatelje i špeditere koji bi sanduke dalje slali na njegovu adresu. Moli Račkoga da se izjasni o njegovu prijedlogu sugerirajući mu da se kao otpravnik navede izvjesni apotekar Catty, s kojim se Rački dobro poznavao i koji je bio njegov zemljak.

Dostavlja mu pismo te u privitku "katalog njekih foliantov" ${ }^{89}$ koji mu je dao Mate Brusić, s namjerom da se obrati Račkome i pita ga bi li Akademija primila te knjige za svoju biblioteku. ${ }^{90}$ Navedene knjige Brusić je dobio od Nikše Gradića, koji ih poklanja Akademiji ako su joj potrebne. Knjige su do sada bile pohranjene u sanduku, a kako Brusić oskudijeva u prostoru, potrebno mu je znati bi li ih Akademija preuzela. Ako je zainteresirana, trebala bi se pobrinuti za sam prijenos i troškove prijenosa. U tadašnjoj Rijeci naime nitko za njih nije bio zainteresiran.

Fiamin veoma iskreno ističe da osjeća stid što još ničim, pa ni materijalno, nije doprinio ni Akademiji ni zagrebačkom Sveučilištu, što s njegovih 1.200 forinti nije ni moglo očekivati, pa se nada da će to nadomjestiti barem s poklonjenim knjigama. ${ }^{91}$

U ožujku 1875. godine Fiamin u Primorskoj tiskari u Kraljevici tiska svoj posljednji prijevod - Kršćanske molitve Nikole Tommasea. ${ }^{92}$ Šalje mu jedan izlistak te tri druga s molbom da mu učini uslugu i da, kad bude imao vremena, jedan pošalje Strossmayeru, uz izraz Fiaminova dubokoga štovanja. On sam ne bi to direktno slao jer smatra da je njegov posao neznatan, a i osjeća nelagodu zbog neprofinjenoga veza tamošnjega knjigoveže. Ispričava se Račkome na ovećoj smionosti oko zadanoga mu zadatka dodajući da mu se može odužiti „kakvomgod ti dragom sličnom ili većom" molbom.

87 Od prvog napisa posvećenog toj temi pod naslovom Nabožne misli o sv. Cirilu i Metodu (Z. k. 1., 12/1854) preko velike studije Slavi slavenskih apoštola (Z. k. 1. 10-24, 26/1855) do djela u dva sveska Viek i djelovanje sv. Cirilla i Metoda slovjenskih apoštolov, Zagreb, 1857., I S·l. i 1859, II; i konačno pril'ikom tisućgodišnjice izdaje Književni rad sv. Cirilla i Metoda, Zagreb, 1863.

88 Riječ je o djelu Pismo Slovjensko, Zagreb, 1861.

89 Misli se na katalog „knjiga velikog formata”, Julije Benešić, Rječnik hrvatskoga književnoga jezika od preporoda do I. G. Kovačića, sv. 3, Zagreb, 1986., str. 495.

90 Rijeka, 13. 6. 1869., AHAZU, XII, A, 155/9.

91 Rijeka, 28. 11. 1869., AHAZU, XII, A, 155/12.

92 Rijeka, 24. 3. 1875., AHAZU, XII, A, 155/22. 


\section{Molba za učenike}

Fiamin je Račkoga molio pomoć za neke od potrebitih učenika. Jedan od njih jest Josip Mavrinac, kojega je, kako navodi u pismu, Račkome već preporučio kapelan Marušić ${ }^{93}$ Mladi Mavrinac prethodnog je ljeta završio nižu gimnaziju, a želja mu je bila završiti dvogodišnji tečaj preparandije i postati učitelj. No, prepreka tome bila su materijalna sredstva koja mladićeva samohrana majka nije imala. Razlog Fiaminova obraćanja Račkome bio je taj što je Modruška biskupija, kojoj je mladić pripadao, već podijelila dvije stipendije koje su ustanovljene za kandidate učiteljstva svoje biskupije. Fiamin je istaknuo kako treba osigurati više stipendija dodavši kako na temelju iskustva zna da je uopće teško ući u krug stipendista. Ispričao se Račkome što ga opterećuje tim pitanjem opravdavši se činjenicom da riječi Račkoga imaju težinu. Napominje kako će on sam mladiću, dok ne primi stipendiju, podmiriti trošak najma stana, a da mu treba naći i obitelj koja bi mu osigurala hranu, a on bi im zauzvrat brinuo o djeci. Dodaje kao dječaku treba pomoći i „,(..) učiniti ovo veliko djelo milosrdja pa to namjenjeno da se negubi a da čovjekom postane, dobre kako je ćudi i u strahu odhranjen". Ako se dječaku navedeni uvjeti ne bi mogli osigurati u Zagrebu, dobro će doći nekoliko riječi F. Račkoga upućenih biskupu Strossmayeru, ne bi li ga primio u preparandiju u Đakovu. $S$ vremenom mladić može dobiti i riječku stipendiju, iako izražava sumnju u to dodajući: „(...) ali sad u kakovih smo rukuh, nejma nade, jer bi se htjela zaštita gnjusov" kakvi su riječki političari.

Jedna od molbi koju je Fiamin uputio Račkome tiče se mladića koji je u Rijeci završio gimnaziju i koji je, ne mogavši dobiti stipendiju ugarske vlade, krenuo $\mathrm{k}$ bratu u Zagreb nadajući se da će mu on pomoći. ${ }^{94}$ No brat je ostao bez stipendije, pa mladić ne zna kome bi se obratio za pomoć. Fiamin pita bi li se u međuvremenu, dok ne stigne kakva stipendijska pomoć, mladić za sredstva mogao obratiti Strossmayeru, stoga moli Račkoga za preporuku kako bi mladić ostao u domovini, jer ako mu ugarska vlada s vremenom da stipendiju, morat će u Peštu te će se na taj način otuđiti od našega kraja. Interesira se bi li mu možda nadbiskup, koji, kako čuje, dijeli stipendije, doskočio. Ali, pretpostavlja, kod nadbiskupa će više šanse imati onaj tko mu je bliži.

93 Rijeka, 11. 9. 1868., AHAZU, XII, A, 155/8.

94 Rijeka, 9. 10. 1877., AHAZU, XII, A, 155/23. 


\section{Društvena djelatnost}

Fiamin se ponekad Račkome ispričavao zbog zakašnjeloga odgovaranja na njegovo pismo. ${ }^{95}$ Tako mu kao jedan od razloga zbog kojega nije stigao odgovoriti spominje priređivanje zabave u riječkoj Čitaonici, za koju je valjalo prevesti komad, u kojemu su igrali gđa Zmajić i Derenčin, a i sam je Fiamin oko toga bio veoma zauzet. Jetko dodaje kako „(...) na Rieci treba nam nješto života pokazati, te ćemo još morda koju imati prije nego nas braća izgone iz Rieke”. Daje naslutiti da riječka Čitaonica financijski i ne stoji baš najbolje; tako ističe da preporučuje pretplatu na Vijenac, ali čitaoničke financije to ne dopuštaju. ${ }^{96}$ Navodi i kako je potrebna velika žrtva „da jedino stecište hrvatsko na Rieci nepropadne”, ali mu ne navodi detaljnije o čemu je riječ već samo dodaje neka im neprimanje Vijenca ne uzima za zlo.

\section{Zaključak}

Preko dvadeset i četiri pisma što ih je riječki svećenik Ivan Fiamin (1833. - 1890.) uputio Franji Račkome možemo pratiti onovremenu atmosferu u različitim aspektima Fiaminova života i u gradu u kojemu djeluje, te kakav je oslonac našao u Račkome povjeravajući mu svoja djela na čitanje i pokoravajući se njegovu sudu. Korespondencija započinje 1861.. i traje sve do 1889. godine, i to s različitim intenzitetom. Prve dvije godine Fiamin korespondira iz Senja, a potom iz Rijeke. Korespondencija je najintenzivnija u periodu između 1869. i 1871. godine, kada je Fiamin sastavio ukupno trinaest pisama, mahom o prijevodima knjiga i nastanku njegove jedine knjige Radnja čovjeku dužnost i blagodat. Sadržaje pisama tematski možemo grupirati u više cjelina: ponajprije o Fiaminovu književnom djelovanju koje je potaknuto i idejom biskupa Jurja Dobrile o velikoj važnosti pisane riječi za hrvatski narod, a tu su i prijevodi knjiga u prvome redu za običan puk. Fiaminova nakladnička djelatnost odvijala se pod utjecajem njegova gimnazijskoga profesora Frana Kurelca, inače osnivača riječke filološke škole, prema čijim je jezičnim uzusima Fiamin i djelovao. Račkome se obraća i vezano uz svoja imenovanja tražeći od njega pomoć i podršku zbog teške političke situacija u tadašnjoj Rijeci, u kojoj dobiva namještenje. S obzirom na funkciju školskoga nadzornika i izvjestitelja za pučke srednje škole koju je Rački obavljao, Fiamin se u korespondenciji dotiče i školskih pitanja vjerujući da će Rački pri njihovu rješavanju biti od pomoći. U kraćim se crtama dotiče i

95 Rijeka, 15. 1. 1870., AHAZU, XII, A, 155/14.

96 Isto. 
distribucije knjiga, materijalne pomoći učenicima te društvene djelatnosti kroz riječku Čitaonicu. Sadržaj pisma pokazuje prijateljski odnos Fiamina i Račkoga, protkan međusobnim povjerenjem i uvažavanjem. 
Maja Polić and Tea Dimnjašević

\section{Ivan Fiamin's Correspondence with Franjo Rački \\ (1861-1889)}

\section{Summary}

The paper tackles the content of the correspondence of Ivan Fiamin, priest in Rijeka, addressed to Dr. Franjo Rački, canon and politician. Ivan Fiamin (1833-1890) completed his primary and secondary education in the former Rijeka, after which he completed the studies at the Vienna Pazmaneum. He first spent a certain period of time in Senj, after which he moved to Rijeka, where he remained until his death. He began his literary work at the instigation of his former grammar school teacher Fran Kurelac, following thereby the philological views of Kurelac's Rijeka philological school. Not only during Fiamin's upbringing, but also much later, Kurelac was his mentor and his support in dealing with numerous issues, particularly the ones of national character, which were not at all insignificant. Fiamin's correspondence addressed to Franjo Rački consists of twenty-four letters and is in the safekeeping at the Archives of the Croatian Academy of Sciences and Arts. The letters tackle Fiamin's literary work, career, school issues, care for students, etc. The objective of the paper is to illuminate-using thereby the historical critical method, the analysis and synthesis methods and the descriptive method - individual segments of Fiamin's life and work.

Keywords: Ivan Fiamin; Franjo Rački; Rijeka; correspondence. 